\title{
Developing Displayed Flipbook as Teaching Material for Assisting Teacher to Teach English in Online Learning for the Fourth Grade Elementary School Students
}

\author{
Dharmayanti, N. M. D ${ }^{1 *}$, Putra, I. N. A. J ${ }^{2}$, Paramartha, A. A. G. Y ${ }^{3}$ iD \\ ${ }^{1,2,3}$ English Language Education, Ganesha University of Education, Singaraja. Indonesia \\ *Corresponding author: dharmayantidwi19@gmail.com
}

\begin{abstract}
Abstrak
Minimnya bahan ajar yang dapat memfasilitasi kemandirian belajar siswa berdampak pada kurangnya pemahaman siswa. Selain itu, kurangnya bahan ajar juga berdampak pada hasil belajar siswa. Tujuan dari penelitian ini adalah untuk membuat bahan ajar dengan Flipbook. Jenis penelitian ini dikembangkan dengan menggunakan tiga tahapan, yaitu desain, pengembangan, dan evaluasi. Pengumpulan data dilakukan melalui wawancara dan analisis dokumen. Ada dua instrumen yang digunakan dalam penelitian ini, yaitu pedoman wawancara dan penilaian ahli. Subjek penelitian ini adalah guru bahasa Inggris. Teknik analisis data yang digunakan adalah analisis deskriptif kualitatif dan kuantitatif. Hasil penelitian menunjukkan bahwa kualitas Flipbook yang dinilai oleh ahli pertama mendapat skor 56. Kualitas penilaian yang diberikan oleh juri ahli kedua adalah 61, dengan kategori baik. Nilai kualitas yang diberikan oleh pengguna adalah 62, dengan kategori baik. Dengan demikian, flipbook dikategorikan sebagai bahan ajar yang sesuai. Sehingga dapat dikatakan bahwa bahan ajar flipped book yang dikembangkan layak untuk diterapkan dalam proses pembelajaran. Penelitian ini menyiratkan bahwa Flipbook yang dikembangkan dapat digunakan oleh siswa dalam belajar mandiri.
\end{abstract}

Kata kunci: Flipbook, Bahan Ajar, Pembelajaran Online

\section{Abstract}

The lack of teaching materials that can facilitate students' independent learning has an impact on students' lack of understanding. In addition, the lack of teaching materials also has an impact on student learning outcomes. The purpose of this research is to create teaching materials with Flipbook. This type of research is developed using three stages, namely design, development, and evaluation. Data was collected through interviews and document analysis. There are two instruments used in this study, namely interview guidelines and expert assessment. The subject of this research is the English teacher. The technique used to analyze the data is descriptive qualitative and quantitative analysis. The results showed that the quality of the Flipbook assessed by the first expert got a score of 56 . The quality assessment given by the second jury expert was 61 , with a good category. The quality rating given by the user is 62 , with a good category. Thus, flipbooks are categorized as suitable teaching materials. So it can be said that the flipped book teaching materials developed are feasible to be applied in the learning process. This research implies that the Flipbook developed can be used by students in an independent study.

Keywords: Flipbook, Teaching Material, Online Learning

$\begin{array}{lll}\text { History: } & & \text { Publisher: Undiksha Press } \\ \text { Received } & : \text { February } 07,2021 & \text { Licensed: This work is licensed under } \\ \text { Revised } & : \text { February } 22,2021 & \text { a Creative Commons Attribution 3.0 License } \\ \text { Accepted } & : \text { March } 30,2021 & \end{array}$

\section{Introduction}

Technological developments in Indonesia nowadays are growing rapidly. Technology becomes a familiar thing among people because technology can help us make something easier to be more effective (Irawan, 2018; Sudjimat \& Luchyto, 2019). Apart from being a lifestyle, technology has also been widely used in education (Mustaqim, 2016; Suranti, Gunawan, \& Sahidu, 2017). Currently, the use of technology in Indonesian schools is used to facilitate the teaching and learning process because, with the help of technology, both teachers and students can find information very easily such as subject matter, videos, and other important information technology also makes it easier for teachers to deliver learning material (Bardi \& Jailani, 2015; Surjono, 2016). Likewise, students can obtain a wide range 
of information from various media sources using cyberspace or using computers or the internet. The benefits of technology for teachers are teachers can help students in delivering material more easily such as using power points, cameras, videos because the explanations are given visually will make the learning process more interesting and enjoyable so teachers can create a more attractive classroom atmosphere (Herawati \& Muhtadi, 2018; Nazalin \& Muhtadi, 2016). In addition to teachers, technology also provides many benefits for students including students becoming more interested in learning, students can do their work freely at home, students can get new skills about technology that can be applied in the world of work later, and can reduce paper waste so the environment stays awake (Bardi \& Jailani, 2015; Raja \& Nagasubramani, 2018).

One of the technologies that are often used in education is in learning English. Besides being used in face-to-face learning conducted in class, the use of technology is also used in online learning. As we know, Indonesia is experiencing a pandemic due to Covid-19, so schools also require their students to do online learning (Durnali, 2020; Wahyono, Husamah, \& Budi, 2020). Online learning is learning that uses internet networks with accessibility, connectivity, flexibility, and the ability where all members interact with to influence knowledge constructed by referring to the individual experience of practice and knowledge of students (Garad, Al-Ansi, \& Qamari, 2021; Mamluah \& Maulidi, 2021). Yet, many schools are still not ready to use online learning, but this must be done, so both teachers and students must be ready for online learning. There are still many teachers who have difficulty in designing online learning (Mamluah \& Maulidi, 2021; Rosmiati \& Lestari, 2021). This causes learning not to run optimally. In addition, there are still many students who have difficulty learning online. Students have difficulty in learning independently, so that it has an impact on low student learning outcomes (Aji, 2020; Wardani, Anita, \& Ayriza, 2020). The lack of learning media that can help students learn independently also affects student learning outcomes (Sidiq \& Najuah, 2020; Wulandari, Abidin, \& Praherdhiono, 2019). However, e-book in online learning has not been used in several schools. There are still many teachers who use teaching materials such as conventional learning in the classroom, which is caused lack of knowledge and experience in developing appropriate teaching materials, lack of socialization and training about the curriculum being applied to the lack of support from schools both financially and non-financially.

One of the schools that have not used an e-book in the online learning process is SD No 5 Jimbaran. Based on the preliminary observations that have been conducted by the researcher, the English teacher in this school has not used e-book as the teaching material, especially in online learning. The teacher only uses printed or conventional books in online learning by taking photos of the books used and then sending them to students and occasionally using instructional videos as a learning medium. In addition, students are assigned to find or buy printed books used in the learning process which is an obstacle for them because students live in different areas where the distribution of school books is different from one to another. Moreover, the books used by students are determined by the school which has the same title and publisher. In addition, some students also complained about the cost of purchasing books, especially in a situation like this, where many parents experience economic difficulties. This causes some students to experience delays in the learning process, for example, their teachers have given assignments but some students do not have books so that the learning process is hampered. Besides, the teacher also has difficulties when teaching materials just rely on printed books because of the above factors, so that e-book can be used as an alternative for teaching English.

One of the things that need to be prepared by the teacher is teaching material. Teaching materials are all forms of material used by teachers in the learning process (Gafur, 2010; Kurniawati, Anitah, \& Suharno, 2017; Puspita, 2019). Teaching materials are a set of 
learning materials or substances that are systematically arranged, and it displays a complete figure of competencies that will be mastered by students and have many functions (Hufri, Dwiridal, \& Sari, 2021; Sriyanto, Leksono, \& Harwanto., 2019). Teaching materials are an important source of material for teachers in carrying out the learning process. Without teaching materials, teachers will have difficulty achieving learning objectives so that teachers must always prepare teaching materials in implementing the learning process (Purwanto \& Rizki, 2014; Puryadi, Rahayu, \& Sutrio, 2018). Given that currently, schools in Indonesia are using online learning, the teaching materials made must be varied and interesting so that students are interested in learning and learning objectives are still achieved, especially in online learning, many students feel bored to learn so that teachers must be able to develop teaching materials.

The findings of previous research stated that E-modules could help students learn independently (Laili, Ganefri, \& Usmeldi, 2019; Wijayanti et al, 2016). Other research findings also state that E-modules make it easier for students to learn to improve student learning outcomes (Darmayasa, Jampel, \& Simamora, 2018; Pramana, Jampel, \& Pudjawan, 2020). There is no study on developing teaching materials with Flipbook that can help teachers teach English learning. The purpose of this research is to create teaching materials with Flipbook. It is hoped that these teaching materials can help students learn independently so that they can improve student learning outcomes.

\section{Methods}

The design used in this research was D\&D (Design and Development) research. The setting of this research was SD No. 5 Jimbaran with the subject was the English teacher. There were two data collection methods used in this research. The first data collection was an interview. In this research, the researcher interviewed the English teacher to find out what problems or shortcomings occur to the teacher when teaching English using teaching material in online learning with the type of interview used was a structured interview. The second data collection method used was document analysis which means a method used to review and evaluate documents, both printed documents and electronic documents (Bowen, 2009). Document analysis used by the research was to choose the topics that will be developed by the researcher from the fourth-grade elementary school English subject syllabus. The research instruments used in this research were an interview guide and expert judgment. The researcher asked several questions that have been made before to the teacher related to the use of teaching material in online learning and the theory of the interview questions. The data analysis method in this research has used the theory from (Richey \& Klein, 2005) which consists of three stages, namely design, development, and evaluation.

\section{Results and Discussion}

The teacher needed to prepare a video as an extra learning material to help students understand the material easily. It was becase the teacher could not deliver the learning material directly. Besides, the preparation was also done by the teacher in teaching using video conferencing like Google Meet. The next difficulty was the availability of teaching materials. Based on the result of teacher interview, the students did not get books from school so they looked for books by borrowing, buying, or photocopying them. Thus, the teacher explained that a flipbook could be a solution for students who were constrained by the teaching materials used in the learning process, especially for the online learning. The use of a flipbook was considered to be the effective and efficient media because the teacher only needed to send it via WhatsApp group in the form of a link and students only needed to click the link. Then, they could read the flipbook freely whenever and wherever they wanted. The 
appearance of the flipbook is similar with a printed book but it was more attractive. The flipbook also included audio to train the students' listening skills. As the result, the students can still master the four English skills during online learning.

After getting the results from the interview, the researcher continued with the document analysis, namely the fourth-grade syllabus of elementary schools used by the teacher in teaching English. In this study, the researcher analyzed the fourth-grade syllabus of even semesters of elementary school students to design a flipbook. Based on the results of the conducted analysis, the syllabus contained four topics, namely times, parts of the body, daily activities, and adjectives. There were two basic competencies (KD) in each topic. Each topic also consisted of four English skills, namely reading, writing, listening, and speaking. The activities in each topic are Let's Read, Language Focus, Write It Down, Listen to It, Sing a Song, Speak It Up, and Exercise. The development stage described three things. The first was the flipbook cover design. Since the Flipbook was intended to be used for the fourth-grade Elementary School students, the cover design was made in a simple, clear, and attractive design. As for the media developed in Figure 1.

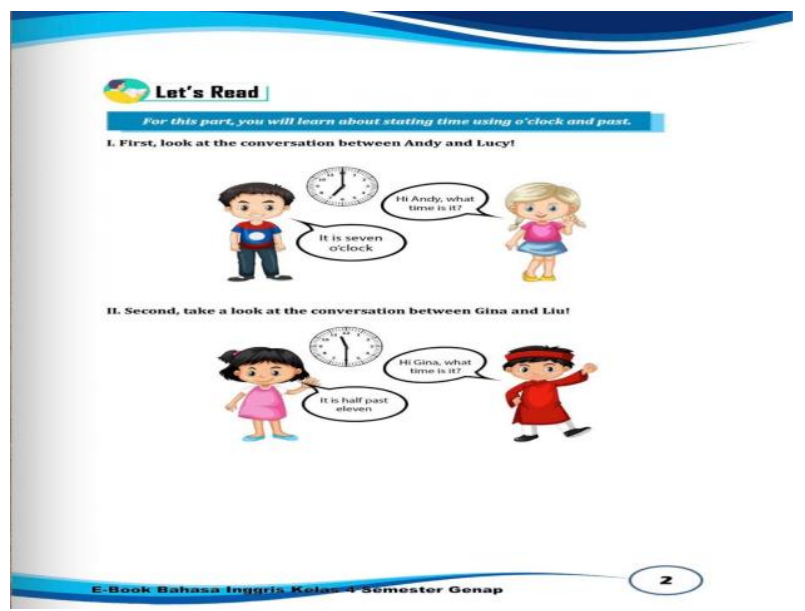

Figure 1. The Flipbook Content

The second was the flipbook content. The researcher made sure that the content was presented consistently throughout the Flipbook. Four chapters were being covered in the Flipbook. Each chapter had its page introduction which was complemented with the details of the subject, class and semester, core competency, basic competency, and learning objectives. Thus, the direction of the learning process was clear for both the teacher and students. After the chapter's introduction page, every chapter had seven sub-chapters that helped the students to learn, comprehend the materials, and develop their four language skills, as well as assess their learning progress. The content was made in the reflection to the subject matters that had firstly developed under the basic competency, indicators, and learning objectives of the topics.

In the evaluation step, there were two kinds of judgment used in this research, namely content validity judgment and quality judgment. The content validity judgment was filled by two expert judges. The two expert judges were the lecturers of the English language Education study program. There were fourteen criteria in the content validity judgment which were used as a reference in assessing the content of the flipbook made by the researcher. The results of the content validity judgment were analyzed using the Gregory Formula. After getting the accumulated scores of each criterion contained in the formula, the results of the quality judgment by the expert judges and user were measured. It was found that the quality judgment given by the first expert judge was 56 in which it was categorized as good. Second, 
the quality judgment was given by the second expert judge was 61 in which it was categorized as good. The quality judgment given by the user was 62 in which it was categorized as good. Thus, the displayed flipbook was categorized as good teaching material. So it can be concluded that the flipped book teaching materials developed are feasible to be applied in the learning process. Several factors, namely as follows, cause this.

The layout design of the Flipbook is made simple yet attractive under the theory who argues that teaching materials must be attractive such as having attractive designs and layouts, so that students are interested in learning (Herawati \& Muhtadi, 2018; Sidiq \& Najuah, 2020). The displayed flipbook created by the researcher has 34 pages with 4 chapters, namely times, parts of the body, daily activities, and adjectives. Each chapter contains four English skills, namely reading, writing, listening, and speaking. The existence of skills developed in this Flipbook is in line with the theory, which states that the material needs to provide several opportunities for students to improve their skills (Khasana, Parmiti, \& Sudatha, 2018; Suhaida \& Fadillah, 2019). Learning materials must be contextual by the syllabus because they represent student achievement (Hufri et al., 2021; Nendasariruna, MAsjudin, \& Abidin, 2018; Suastika \& Amaylyla, 2019).Therefore, the learning materials in Flipbook are specifically designed to reflect essential competencies, indicators, learning, and subject matter. Then, the content validity of the flipbooks displayed was assessed using a content validity assessment. Two expert judges in this field assessed the validity of the flipbook content displayed. The results of the validity assessment show that the Flipbook displayed is very relevant to the criteria for suitable learning materials.

The use of songs in Flipbook is related to the theory, which states that the material should help increase students' self-confidence (Rahmawati, Irdamurni, \& Amini, 2019; Santoso, 2017). Songs have a positive influence on students' vocabulary retention (Lestari, Kristiantari, \& Ganing, 2017; Rani, Ardana, \& Negara, 2019). Whatever setting is used, aural or aural/visual, the results lend themselves well to proving that the songs are for different learning styles. They encourage positive and uplifting learning experiences for students. Teaching materials can improve students' attitudes and learning motivation because they are faced directly with the interpretation of learning in class and interpretations in students' real life with a more relaxed learning atmosphere, so the songs used are expected to provide a relaxed atmosphere for students (Martha \& Andini, 2019; Purnomo \& Wilujeng, 2016). Therefore, the use of songs and revisions is expected to create confidence and hope in learning. Flipbooks as technology-based teaching materials that help in the learning process were supported by (Simatupang, Purnama, \& Simatupang, 2020; Sriyanti, Almafie, Marlina, \& Jauhari, 2021; Triwahyuningtyas, Ningtyas, \& Rahayu, 2020). Flipbook also has a sound that helps students practice listening skills (Nisa, Ismet, \& Andriani, 2020). In terms of sound, namely the use of e-modules in 3D Flipbooks, including sound, video, flash, hyperlinks. Moreover, the flipbook also presents pictures that help students understand the material easily (Azizah et al., 2020).

The findings of previous studies also stated that E-modules could increase students' learning motivation (Asrial, et al,. 2020; Suarsana \& Mahayukti, 2013). Other research findings also state that E-modules can help students learn (Aprilia \& Suryadarma, 2020; Ningsih \& Mahyuddin, 2021). However, this current study has differences from previous studies. The displayed flipbook in this study was made for online learning, especially in the COVID-19 pandemic situation. The flipbook is designed to teach English to grade 4 elementary school students. The displayed flipbook made by the researcher presents the four English skills, namely reading, writing, listening, and speaking in each chapter on the flipbook. So, the skills taught are integrated and students can master English skills even though learning is carried out online. It was related to (Howard \& Major, 2004), namely that teaching materials should contain integrated skills so that students can have broader 
knowledge. The contents consist of seven sub-chapters, which are Let's Read, Language Focus, Write It Down, Listen to It, Sing a Song, Speak It Up, and Exercise. Thus, the flipbook as teaching materials had novelties from those developed flipbooks from previous studies.

\section{Conclusion}

The flipbook teaching materials developed are categorized as very good, so they are suitable for learning. It is recommended that teachers use flipbook teaching materials to make it easier for students to learn independently.

\section{References}

Aji, R. H. S. (2020). Dampak Covid-19 pada Pendidikan di Indonesia: Sekolah, Keterampilan, dan Proses Pembelajaran $\square$ Dampak Covid-19 pada Pendidikan di Indonesia: Sekolah, Keterampilan, dan Proses Pembelajaran. Jurnal Sosial \& Budaya Syar-I, 5(1), 395-402. https://doi.org/10.15408/sjsbs.v7i5.15314.

Aprilia, I., \& Suryadarma, I. G. P. (2020). E-Module of Mangrove Ecosystem (EMME): Development, Validation, and Effectiveness in Improving Students' Self-Regulated. Biosfer: Jurnal Pendidikan, 13(1), 114-129. https://doi.org/https://doi.org/10.21009/biosferjpb.v13n1.114-129.

Asrial, Syahrial, Maison, Kurniawan, \& Piyana. (2020). Ethnoconstructivism E-Module to Improve Perception, Interest, And Motivation of Students in Class V Elementary School. Jurnal Pendidikan Indonesia, 9(1), 30-41. https://doi.org/10.23887/jpiundiksha.v9i1.19222.

Bardi, \& Jailani. (2015). Pengembangan Multimedia Berbasis Komputer Untuk Pembelajaran Matematika Bagi Siswa SMA Pendidikan. Jurnal Inovasi Teknologi, 2(1), 49-63. https://doi.org/https://doi.org/10.21831/tp.v2i1.5203.

Bowen, G. A. (2009). Document analysis as a qualitative research method. Qualitative Research Journal, 9(2), 27-40. https://doi.org/10.3316/QRJ0902027.

Darmayasa, I. K., Jampel, N., \& Simamora, A. H. (2018). Pengembangan E-Modul Ipa Berorientasi Pendidikan Karakter Di Smp Negeri 1 Singaraja. Jurnal Edutech Undiksha, 6(1), 53-65. https://doi.org/http://dx.doi.org/10.23887/jeu.v6i1.20267.

Durnali, M. (2020). The effect of self-directed learning on the relationship between selfleadership and online learning among university students in Turkey. Tuning Journal for Higher Education, 8(1), 129-165. https://doi.org/http://dx.doi.org/10.18543/tjhe8(1)-2020pp129-165 Received.

Education, B., Surabaya, U. N., Education, B., \& Surabaya, U. N. (2020). The Relationship Of Illustrative Content In Flipbook Type Of E-Book As An Illustrative Learning Media In Immune System With Reading Test Results Using Fry Graphics Vania Nur Azizah Widowati Budijastuti. 9(1), 109-114.

Gafur, A. (2010). Konsep, Prinsip, dan Prosedur Pengembangan Modul Sebagai Bahan Ajar. Jurnal Civics Media Kajian Kewarganegaraan, 7(1). https://doi.org/https://doi.org/10.21831/civics.v7i1.3445.

Garad, A., Al-Ansi, A. M., \& Qamari, I. N. (2021). The Role Of E-Learning Infrastructure And Cognitive Competence In Distance Learning Effectiveness During The Covid-19 $40(1)$. https://doi.org/https://doi.org/10.21831/cp.v40i1.33474.

Herawati, N. S., \& Muhtadi, A. (2018). Pengembangan Modul Elektronik (E-Modul) Interaktif Pada Mata Pelajaran Kimia kelas XI SMA. Jurnal Inovasi Teknologi Pendidikan, 5(2), 180-191. https://doi.org/https://doi.org/10.21831/jitp.v5i2.15424. 
Howard, J., \& Major, J. (2004). Guidelines for designing effective English language teaching materials. 9th Conference of Pan Pacific Association of ..., 101-109.

Hufri, H., Dwiridal, L., \& Sari, S. Y. (2021). Peningkatan Kompetensi Guru-Guru IPA SMP/MTsN Lubuk Sikaping melalui Pelatihan Pengembangan Bahan Ajar Berbasis Kontekstual. Jurnal Pengabdian Kepada Masyarakat, 6(1). https://doi.org/https://doi.org/10.30653/002.202161.502.

Irawan, H. (2018). Keefektifan E-Learning Sebagai Media Pembelajaran (Studi Evaluasi Model Pembelajaran E-Learning Smk Telkom Sandhy Putra Purwokerto). Jurnal Inovasi Teknologi Pendidikan, 5(1), 1-11. https://doi.org/https://doi.org/10.21831/jpv.v3i1.1584.

Khasana, I. N., Parmiti, D. P., \& Sudatha, I. G. W. (2018). Pengembangan Media Monopoli Dengan Model Hannafin Dan Peck Mata Pelajaran Ips Di Sd Mutiara Singaraja. Jurnal Jurusan Teknologi Pendidikan, 6(2), 205-214. https://doi.org/http://dx.doi.org/10.23887/jeu.v6i2.20292.

Kurniawati, M. W., Anitah, S., \& Suharno, S. (2017). Developing Learning Science Teaching Materials Based on Scientific to Improve Student Learning Outcome in Elementary School. European Journal of Education Studies, (20), 319-330. https://doi.org/10.5281/zenodo.398991.

Laili, Ganefri, \& Usmeldi. (2019). Efektivitas Pengembangan E-Modul Project Based Learning pada Mata Pelajaran Instalasi Motor Listrik. Jurnal Ilmiah Pendidikan Dan Pembelajaran, 3(3). https://doi.org/http://dx.doi.org/10.23887/jipp.v3i3.21840. 306309.

Lestari, Kristiantari, \& Ganing. (2017). Pengaruh Model Pembelajaran Talking Stick Berbantuan Lagu Daerah Terhadap Hasil Belajar IPS. International Journal of Elementary Education, $4(1)$. https://doi.org/http://dx.doi.org/10.23887/ijee.v1i4.12960.

Mamluah, S. K., \& Maulidi, A. (2021). Pembelajaran Jarak Jauh (PJJ) di Masa Pandemi COVID-19 di Sekolah Dasar. Jurnal Basicedu, 5(2). https://doi.org/https://doi.org/10.31004/basicedu.v5i2.800.

Martha, nia ulfa, \& Andini, novita pri. (2019). Pengembangan Bahan Ajar Mata Pelajaran Bahasa Indonesia Berbasis Cerita Rakyat Kabupaten Banjarnegara. Jurnal Inovasi Pembelajaran, 5(2). https://doi.org/https://doi.org/10.22219/jinop.v5i2.9992.

Mustaqim, I. (2016). Multimedia services on top of M3 Smart Spaces. Jurnal Pendidikan Teknologi Dan Kejuruan, 13(2), 174. https://doi.org/DOI: http://dx.doi.org/10.23887/jptk-undiksha.v13i2.8525.

Nazalin, \& Muhtadi, A. (2016). Pengembangan Multimedia Interaktif Pembelajaran Kimia Pada Materi Hidrokarbon Untuk Siswa Kelas XI SMA. Jurnal Inovasi Teknologi Pendidikan, 3(2), 221-236. https://doi.org/https://doi.org/10.21831/jitp.v3i2.7359.

Nendasariruna, T., MAsjudin, \& Abidin, Z. (2018). Pengembangan komik matematika berbasis kontekstual pada materi persegi panjang bagi siswa kelas vii. Jurnal Media Pendidikan Matematika, $4(2)$ 76-79. https://doi.org/https://doi.org/10.33394/mpm.v4i2.374.

Ningsih, S. Y., \& Mahyuddin, N. (2021). Desain E-Module Tematik Berbasis Kesantunan Berbahasa Anak Usia Dini di Taman Kanak-Kanak. Jurnal Obsesi: Jurnal Pendidikan Anak Usia Dini, 6(1), 137-149. https://doi.org/10.31004/obsesi.v6i1.1217.

Nisa, W. L., Ismet, I., \& Andriani, N. (2020). Development of E-Modules Based on Multirepresentations in Solid-State Physics Introductory Subject. Berkala Ilmiah Pendidikan Fisika, 8(2), 73. https://doi.org/10.20527/bipf.v8i1.7690.

Pramana, Jampel, \& Pudjawan. (2020). Meningkatkan Hasil Belajar Biologi Melalui E- 
Modul Berbasis Problem Based Learning. Jurnal Edutech Undiksha, 8(2), 18-32. https://doi.org/http://dx.doi.org/10.23887/jeu.v8i2.28921.

Purnomo, H., \& Wilujeng, I. (2016). Pengembangan Bahan Ajar dan Instrumen Penilaian IPA Tema Indahnya Negeriku Penyempurnaan Buku Guru dan Siswa Kurikulum 2013. Jurnal Prima Edukasia, 4(1), 67-68. https://doi.org/https://doi.org/10.21831/jpe.v4i1.7697.

Purwanto, Y., \& Rizki, S. (2014). Pengembangan Bahan Ajar Berbasis Kontekstual Pada Materi Himpunan Berbantu Video Pembelajaran. Jurnal Aksioma, 1. https://doi.org/https://doi.org/10.24127/ajpm.v4i1.95.

Puryadi, P., Rahayu, S., \& Sutrio, S. (2018). Pengaruh Model Pembelajaran Direct Instruction Berbantuan Bahan Ajar Berbasis Kontekstual Terhadap Hasil Belajar IPA Terapan Siswa Kelas X SMKN 4 Mataram Tahun Ajaran 2015/2016. Jurnal Pendidikan Fisika Dan Teknologi, https://doi.org/https://doi.org/10.29303/jpft.v4i1.329.

Puspita, L. (2019). Pengembangan Modul Berbasis Keterampilan Proses Sains Sebagai Bahan Ajar Dalam Pembelajaran Biologi. Jurnal Inovasi Pendidikan IPA, 5(1), 7987. https://doi.org/https://doi.org/10.21831/jipi.v5i1.22530.

Rahmawati, E., Irdamurni, I., \& Amini, R. (2019). Pengembangan Modul Berbasis Pendekatan Kontekstual Dengan Adobe Flash Untuk Siswa Sekolah Dasar. Jurnal Basicedu, 3(2). https://doi.org/https://doi.org/10.31004/basicedu.v3i2.29.

Raja, R., \& Nagasubramani, P. C. (2018). Impact of modern technology in education. Journal of Applied and Advanced Research, 3(S1), 33. https://doi.org/10.21839/jaar.2018.v3is1.165.

Rani, Ardana, \& Negara. (2019). Pengaruh Model Pembelajaran Talking Stick Berbantuan Lagu Tradisional Terhadap Kompetensi Pengetahuan IPA. Jurnal Mimbar Ilmu, 24(3). https://doi.org/http://dx.doi.org/10.23887/mi.v24i3.21676.

Richey, R. C., \& Klein, J. D. (2005). Developmental research methods: Creating knowledge from instructional design and development practice. Journal of Computing in Higher Education, 16(2), 23-38. https://doi.org/10.1007/BF02961473.

Rosmiati, U., \& Lestari, P. (2021). Inovasi Model Pembelajaran PBI ( Problem Based Instruction ) Berbasis Whatsapp Sebagai Langkah Solutif Pembelajaran di Masa Pandemi Covid-19. JNPM (Jurnal Nasional Pendidikan Matematika), 5(1), 188-197. https://doi.org/http://dx.doi.org/10.33603/jnpm.v5i1.3708 Inovasi.

Santoso, E. (2017). Penggunaan Model Pembelajaran Kontekstual Untuk Meningkatkan Kemampuan Pemahaman Matematika Siswa Sekolah Dasar. Jurnal Cakrawala Pendas, 3(1). https://doi.org/http://dx.doi.org/10.31949/jcp.v3i1.407.

Sidiq, R., \& Najuah. (2020). Pengembangan E-Modul Interaktif Berbasis Android Pada Mata Kuliah Strategi Belajar Mengajar. Jurnal Pendidikan Sejarah, 9(1), 1-14. https://doi.org/https://doi.org/10.21009/JPS.091.01.

Simatupang, H., Purnama, D., \& Simatupang, Z. (2020). The Development of Best Practice Handbook Learning Strategy Based on Flip Book to Support Blended Learning Processes. Journal of Physics: Conference Series, 1462(1). https://doi.org/10.1088/1742-6596/1462/1/012014.

Sriyanti, I., Almafie, M. R., Marlina, L., \& Jauhari, J. (2021). The effect of Using FlipbookBased E-modules on Student Learning Outcomes. Kasuari: Physics Education Journal (KPEJ), 3(2), 69-75. https://doi.org/10.37891/kpej.v3i2.156.

Sriyanto, Leksono, \& Harwanto. (2019). Bahan Ajar PPKn Berbasis Karakter dan Literasi Untuk Siswa Kelas IX SMP Al Hikmah Surabaya. Edmotech, 4(2), 130-142. https://doi.org/http://dx.doi.org/10.17977/um039v4i22019p130.

Suarsana, I. M., \& Mahayukti, G. A. (2013). Pengembangan E-Modul Berorientasi 
Pemecahan Masalah Untuk Meningkatkan Keterampilan Berpikir Kritis Mahasiswa. Jurnal Nasional Pendidikan Teknik Informatika (JANAPATI), 2(3), 193. https://doi.org/10.23887/janapati.v2i3.9800.

Suastika, I. K., \& Amaylyla. (2019). Pengembangan modul pembelajaran matematika dengan pendekatan kontekstual. Jurnal Pendidikan Matematika Indonesia, 4(2). https://doi.org/https://dx.doi.org/10.26737/jpmi.v4i2.1230.

Sudjimat, D. A., \& Luchyto. (2019). Effect Of Work-Based Learning Model On Students' Achievement Motivation. Jurnal Pendidikan Teknologi Dan Kejuruan, 25(2). https://doi.org/https://doi.org/10.21831/jptk.v25i2.24416.

Suhaida, D., \& Fadillah, S. (2019). Media Kajian Kewarganegaraan membentuk karakter siswa. Jurnal Civics: Media Kajian Kewarganegaraan, 16(2), 111-121. https://doi.org/https://doi.org/10.21831/jc.v16i2.21757.

Suranti, N. M. Y., Gunawan, G., \& Sahidu, H. (2017). Pengaruh Model Project Based Learning Berbantuan Media Virtual Terhadap Penguasaan Konsep Peserta didik pada Materi Alat-alat Optik. JPFT (Jurnal Pendidikan Fisika Dan Teknologi), 2(2). https://doi.org/https://doi.org/10.29303/jpft.v2i2.292.

Surjono, J. (2016). Pengembangan Multimedia Pembelajaran Bahasa Inggris Untuk Pembelajaran Teks Recount Di Mtsn II Yogyakarta. Jurnal Inovasi Teknologi Pendidikan, 3(1), 25-39. https://doi.org/https://doi.org/10.21831/tp.v3i1.8287.

Triwahyuningtyas, D., Ningtyas, A. S., \& Rahayu, S. (2020). The problem-based learning emodule of planes using Kvisoft Flipbook Maker for elementary school students. Jurnal Prima Edukasia, 8(2), 199-208. https://doi.org/10.21831/jpe.v8i2.34446.

Wahyono, P., Husamah, H., \& Budi, A. S. (2020). Guru profesional di masa pandemi COVID-19: Review implementasi, tantangan, dan solusi pembelajaran daring. Jurnal Pendidikan Profesi Guru, 1(1), 51-65. https://doi.org/https://doi.org/10.22219/jppg.v1i1.12462.

Wardani, Anita, \& Ayriza, Y. (2020). Analisis Kendala Orangtua dalam Mendampingi Anak Belajar di Rumah Pada Masa Pandemi Covid-19. Jurnal Pendidikan Anak Usia Dini, 5(1). https://doi.org/https://doi.org/10.31004/obsesi.v5i1.705.

Wijayanti, N. P. A., Damayanthi, L. P. E., Sunarya, I. M. G., \& Putrama, I. M. (2016). Pengembangan E-Modul Berbasis Project Based Learning Pada Mata Pelajaran Simulasi Digital Untuk Siswa Kelas X Studi Kasus di SMK Negeri 2 Singaraja. Jurnal Pendidikan Teknologi Dan Kejuruan, 13(2), 184-197. https://doi.org/http://dx.doi.org/10.23887/jptk-undiksha.v13i2.8526.

Wulandari, V., Abidin, Z., \& Praherdhiono, H. (2019). Pengembangan Media Pembelajaran E-Book Infografis Sebagai Penguatan Kognitif Siswa X MIA. Jurnal Kajian Teknologi Pendidikan, 2(1), 37-44. https://doi.org/http://dx.doi.org/10.17977/um038v2i12019p037. 